\title{
The Profile of Students Creative Thinking Skill in Designing Optical Instruments Prototype
}

\author{
Salman Alfarisi ${ }^{1}$, Irma Rahma S. ${ }^{2}$, and Lilik Hasanah ${ }^{3}$ \\ \{salmanalfarisi@upi.edu ${ }^{1}$ \}

\begin{abstract}
Physics Education Study Program, School of Postgraduate, Indonesia University of Science Education, Indonesia University of Education, Bandung, Indonesia ${ }^{2,3}$
\end{abstract} \\ Education, Bandung, Indonesia ${ }^{1}$, Physics Education Study Program, Faculty of Mathematics and
}

\begin{abstract}
The paper explained the profile of students' creative thinking skills in designing an optical instrument prototype. The research method used a mixed-method with the explanatory sequential design model. The research design was experimental. The subject of this study consist of 22 students on the 11 th grade in one of Senior high school. Students were assigned to design a prototype which is the problem solution of optical tools practice. The instrument of assessment design used in this research was an assessment of the design process that consists of 5 assessment aspects that implicated STEM field (Science, Technology, Engineering, and Mathematics). The result of this study showed by using STEM approach method, students can think creatively in the process of design with a percentage rate of around $66.25 \%$.
\end{abstract}

Keywords: Instrument, Prototype, STEM (Science, Technology, Engineering, and Mathematics) Field.

\section{Introduction}

The data that has been explored by the Global Creativity Index which reviewed from technology and talent aspects, showed that Indonesia is on the 115 ranks from 139 [1]. A growing urgency to prepare students for 21st century challenges has many educators looking for new instructional approaches. In the 2013 curriculum, there are several competencies and expertise that want to be trained through the implementation of learning, one of which is the ability to think creatively [2]. Creative thinking skill produces new things [3]. Creative thinking skill comprises fluency of thinking, the flexibility of thinking and originality of thinking [3]. Learning that integrated into STEM could improve students to get used to solving the problem that has been discovered in the real-life [4]. STEM is learning that combines different disciplines Science, Technology, Engineering, and Mathematics which are integrated [4]

These four aspects are compatible partner among happening problems in the real-life [5], in STEM learning, creativity and knowledge are used parallel by the students [6]. The stem education framework is a new framework for preparing human resources capable of competing and ready to face challenges in this century globally. The basic framework for stem education is the integration of science, technology, engineering, and mathematics.[7]. One of the capabilities involved in STEM is the ability of the design process (Engineering design 
process). The purpose of the stem itself is to prepare students to be able to apply their knowledge to solve complex problems and develop STEM competencies [8]. engineering as both a body of knowledge about the design and creation of human-made products and a process for solving problems [9]. The ability of the design process in the stem domain can refer to the engineering stages or commonly known as the engineering design process (EDP). The engineering design process is the formulation of plans or schemes to assist an engineer in creating a product. This engineering design process consists of steps including research, conceptualization, feasibility assessment, design, planning, and production[10]. The researcher expects this article can be useful to obtain a research overview regarding students' creative thinking skills with a STEM approach in the process of prototype design in optical instruments material.

\section{Method}

\subsection{Design}

The research method used in this research is mixed-method with the explanatory sequential design model. collection and analysis of quantitative data in the first stage using a design process assessment sheet followed by the collection and analysis of qualitative data in the second stage which is built on the initial quantitative results. The research design is an experiment.

\subsection{Participant}

The research subject consists of 22 Grade XI students in one of senior high school in Jambi, consisted of 7 male students, and 15 female students around 16-17 years old.

\subsection{Instrument}

An instrument used in this research is the evaluation of the design process by adapting the rubric made by Ernst \& Glennie [11]. The rubric then has been modified and adjusted to this research. Before conducting an evaluation, students are asked to sit in a group and get the problems to find the solution. There are steps in giving problems such as; including the design proses in creating a product of optical instruments material. The solutions and design process offered by students are assessed by using assessment sheets. There are 5 assessment aspects and 4 assessment scales from assessment evaluation related to creative thinking skills. Each problem that has been offered had an appropriate assessment with the assessment aspect. Assessment aspect is presented in this table 1.

Table 1. Design Process Assessment.

\begin{tabular}{|c|c|c|c|c|c|c|}
\hline \multirow[b]{2}{*}{ Phase } & \multirow[b]{2}{*}{$\begin{array}{l}\text { The } \\
\text { discipline } \\
\text { of } \\
\text { knowledge } \\
\text { involved }\end{array}$} & \multirow[b]{2}{*}{ Aspect } & \multicolumn{4}{|c|}{ Scale } \\
\hline & & & $\begin{array}{l}1 \\
\text { Beginning to } \\
\text { Attain } \\
\text { Standard }\end{array}$ & $\begin{array}{l}2 \\
\text { Nearly } \\
\text { Attained } \\
\text { Standard } \\
\end{array}$ & $\begin{array}{l}3 \\
\text { Achieved } \\
\text { standard }\end{array}$ & $\begin{array}{l}4 \\
\text { Exceeded } \\
\text { standard }\end{array}$ \\
\hline 1 & Science & Choice & Solution & The solutions & The & \\
\hline
\end{tabular}




\begin{tabular}{|c|c|c|c|c|c|c|}
\hline \multirow[b]{2}{*}{ Phase } & \multirow[b]{2}{*}{$\begin{array}{l}\text { The } \\
\text { discipline } \\
\text { of } \\
\text { knowledge } \\
\text { involved }\end{array}$} & \multirow[b]{2}{*}{ Aspect } & \multicolumn{4}{|c|}{ Scale } \\
\hline & & & $\begin{array}{l}1 \\
\text { Beginning to } \\
\text { Attain } \\
\text { Standard }\end{array}$ & $\begin{array}{l}2 \\
\text { Nearly } \\
\text { Attained } \\
\text { Standard } \\
\end{array}$ & $\begin{array}{l}3 \\
\text { Achieved } \\
\text { standard }\end{array}$ & $\begin{array}{l}4 \\
\text { Exceeded } \\
\text { standard }\end{array}$ \\
\hline & & $\begin{array}{l}\text { of } \\
\text { problem } \\
\text { solution }\end{array}$ & $\begin{array}{l}\text { does not suit } \\
\text { the } \\
\text { background } \\
\text { of the } \\
\text { problem }\end{array}$ & $\begin{array}{l}\text { provided are } \\
\text { not } \\
\text { appropriate } \\
\text { with the } \\
\text { background of } \\
\text { the problem, } \\
\text { but the } \\
\text { underlying } \\
\text { reasons are } \\
\text { not strong } \\
\text { enough }\end{array}$ & $\begin{array}{l}\text { solutions } \\
\text { provided are } \\
\text { according to } \\
\text { the } \\
\text { background } \\
\text { of the } \\
\text { problem. } \\
\text { The } \\
\text { underlying } \\
\text { reason is } \\
\text { strong }\end{array}$ & $\begin{array}{l}\text { The solution } \\
\text { provided } \\
\text { exceeds the } \\
\text { expected } \\
\text { standard } \\
\text { (improvised) } \\
\text { the } \\
\text { underlying } \\
\text { reason is } \\
\text { strong. }\end{array}$ \\
\hline 2 & Science & $\begin{array}{l}\text { Image } \\
\text { forming } \\
\text { of } \\
\text { shadow }\end{array}$ & $\begin{array}{l}\text { Image is not } \\
\text { accompanied } \\
\text { by the } \\
\text { forming of } \\
\text { shadow lines }\end{array}$ & $\begin{array}{l}\text { The picture is } \\
\text { accompanied } \\
\text { by the } \\
\text { forming of } \\
\text { shadow lines } \\
\text { but not } \\
\text { accompanied } \\
\text { by images of } \\
\text { objects and } \\
\text { images of eye } \\
\text { position }\end{array}$ & $\begin{array}{l}\text { The picture } \\
\text { is } \\
\text { accompanied } \\
\text { by the } \\
\text { formation of } \\
\text { shadow } \\
\text { lines, but not } \\
\text { accompanied } \\
\text { by images of } \\
\text { objects and } \\
\text { images of } \\
\text { eye position. } \\
\text { But the } \\
\text { arrow } \\
\text { pointer is } \\
\text { wrong }\end{array}$ & $\begin{array}{l}\text { The line of } \\
\text { formation of } \\
\text { the shadow } \\
\text { but not } \\
\text { accompanied } \\
\text { by an image } \\
\text { of an object } \\
\text { and an } \\
\text { image of the } \\
\text { eye's } \\
\text { position are } \\
\text { indicated by } \\
\text { the correct } \\
\text { arrow } \\
\text { pointer }\end{array}$ \\
\hline 3 & $\begin{array}{l}\text { Science, } \\
\text { technology } \\
\text { and } \\
\text { engineering }\end{array}$ & $\begin{array}{l}\text { Periscope } \\
\text { whole } \\
\text { design }\end{array}$ & $\begin{array}{l}\text { Periscope } \\
\text { design is } \\
\text { drawn in } \\
\text { origin and } \\
\text { does not } \\
\text { include the } \\
\text { description } \\
\text { and } \\
\text { appearance } \\
\text { of the inside }\end{array}$ & $\begin{array}{l}\text { The periscope } \\
\text { design drawn } \\
\text { as a whole } \\
\text { includes the } \\
\text { appearance of } \\
\text { the inside of } \\
\text { the periscope }\end{array}$ & $\begin{array}{l}\text { The } \\
\text { periscope } \\
\text { body design } \\
\text { is drawn as a } \\
\text { whole, } \\
\text { including the } \\
\text { appearance } \\
\text { of the parts } \\
\text { in the } \\
\text { preparation } \\
\text { of different } \\
\text { periscopes } \\
\text { marked with } \\
\text { different } \\
\text { shades and } \\
\text { patterns }\end{array}$ & $\begin{array}{l}\text { The } \\
\text { periscope } \\
\text { body design } \\
\text { is drawn as a } \\
\text { whole, } \\
\text { including the } \\
\text { appearance } \\
\text { of the inside } \\
\text { of the } \\
\text { periscope. } \\
\text { Each } \\
\text { different } \\
\text { periscope } \\
\text { part, shaded } \\
\text { / colored } \\
\text { with a } \\
\text { different } \\
\text { pattern. Each } \\
\text { part is drawn } \\
\text { and given a }\end{array}$ \\
\hline
\end{tabular}




\begin{tabular}{|c|c|c|c|c|c|c|}
\hline \multirow[b]{2}{*}{ Phase } & \multirow[b]{2}{*}{$\begin{array}{l}\text { The } \\
\text { discipline } \\
\text { of } \\
\text { knowledge } \\
\text { involved }\end{array}$} & \multirow[b]{2}{*}{ Aspect } & \multicolumn{4}{|c|}{ Scale } \\
\hline & & & $\begin{array}{l}1 \\
\text { Beginning to } \\
\text { Attain } \\
\text { Standard }\end{array}$ & $\begin{array}{l}2 \\
\text { Nearly } \\
\text { Attained } \\
\text { Standard }\end{array}$ & $\begin{array}{l}3 \\
\text { Achieved } \\
\text { standard }\end{array}$ & $\begin{array}{l}4 \\
\text { Exceeded } \\
\text { standard }\end{array}$ \\
\hline & & & & & & $\begin{array}{l}\text { complete } \\
\text { description }\end{array}$ \\
\hline 4 & Mathematic & $\begin{array}{l}\text { Scale } \\
\text { design of } \\
\text { parts }\end{array}$ & $\begin{array}{l}\text { Create a } \\
\text { periscope } \\
\text { section } \\
\text { stretch } \\
\text { design } \\
\text { without } \\
\text { networking } \\
\text { and without } \\
\text { scaling }\end{array}$ & $\begin{array}{l}\text { Make a } \\
\text { stretch of the } \\
\text { periscope part } \\
\text { of the } \\
\text { network } \\
\text { without the } \\
\text { proper scale } \\
\text { designation. }\end{array}$ & $\begin{array}{l}\text { Creating a } \\
\text { periscope } \\
\text { section } \\
\text { design with a } \\
\text { network that } \\
\text { is } \\
\text { accompanied } \\
\text { by an } \\
\text { appropriate } \\
\text { scale but not } \\
\text { in } \\
\text { accordance } \\
\text { with the } \\
\text { results of the } \\
\text { product } \\
\text { being made }\end{array}$ & $\begin{array}{l}\text { Creating a } \\
\text { periscope } \\
\text { section } \\
\text { design with } \\
\text { a network } \\
\text { that is } \\
\text { accompanied } \\
\text { by an } \\
\text { appropriate } \\
\text { scale and in } \\
\text { accordance } \\
\text { with the } \\
\text { results of the } \\
\text { product } \\
\text { being made }\end{array}$ \\
\hline 5 & $\begin{array}{l}\text { Technology } \\
\text { and } \\
\text { Engineering }\end{array}$ & $\begin{array}{l}\text { Material } \\
\text { selection }\end{array}$ & $\begin{array}{l}\text { Selection of } \\
\text { inappropriate } \\
\text { material (not } \\
\text { strong } \\
\text { enough to be } \\
\text { made into } \\
\text { periscope } \\
\text { forming } \\
\text { components) }\end{array}$ & $\begin{array}{l}\text { Selection of } \\
\text { the } \\
\text { appropriate } \\
\text { material } \\
\text { (strong to be } \\
\text { made into } \\
\text { periscope } \\
\text { forming } \\
\text { components) } \\
\text { but not right } \\
\text { in } \\
\text { argumentation } \\
\text { and not in } \\
\text { accordance } \\
\text { with product } \\
\text { results }\end{array}$ & $\begin{array}{l}\text { Selection of } \\
\text { suitable } \\
\text { materials } \\
\text { (strong to be } \\
\text { made into } \\
\text { periscope } \\
\text { forming } \\
\text { components) } \\
\text { in } \\
\text { accordance } \\
\text { with the } \\
\text { results of the } \\
\text { product but } \\
\text { not logically } \\
\text { appropriate } \\
\text { to the } \\
\text { problem }\end{array}$ & $\begin{array}{l}\text { Material } \\
\text { selection is } \\
\text { more than } \\
\text { the standard } \\
\text { and in } \\
\text { accordance } \\
\text { with the } \\
\text { background } \\
\text { of the } \\
\text { problem / } \\
\text { purpose }\end{array}$ \\
\hline
\end{tabular}

\subsection{Data Analysis}

To investigate students' creative thinking skills in the designing process, first the writer calculating the point that already obtained by grouping students with the standard in table 1 . The total number of point that gets from students are divided with an overall total point that multiplied with percent to see the percentage of students' achievement in that aspect [8]. The calculation result will be interpreted to some categories such as; very good, good, enough, less, very less [9]. The categorization is conducted to see achievement result process of students' design in a grouping or overall students in a class. Here is the table interpretation that users could be seen in table 2 . 
Table 2. Interpretation Percentage Design Process.

\begin{tabular}{ll}
\hline Percentage $(\%)$ & Interpretation \\
\hline $81-100$ & Very Good \\
$61-80$ & Good \\
$41-60$ & Enough \\
$21-40$ & Less \\
$0-20$ & Very Less \\
\hline
\end{tabular}

\section{Result and Discussion}

According to the finding and data analysis of ability profile students creative thinking in overall designing process with score 66.25 is on the good intrepretation. While percentage of each aspects has variative score. This is shown in the diagram Figure 1.

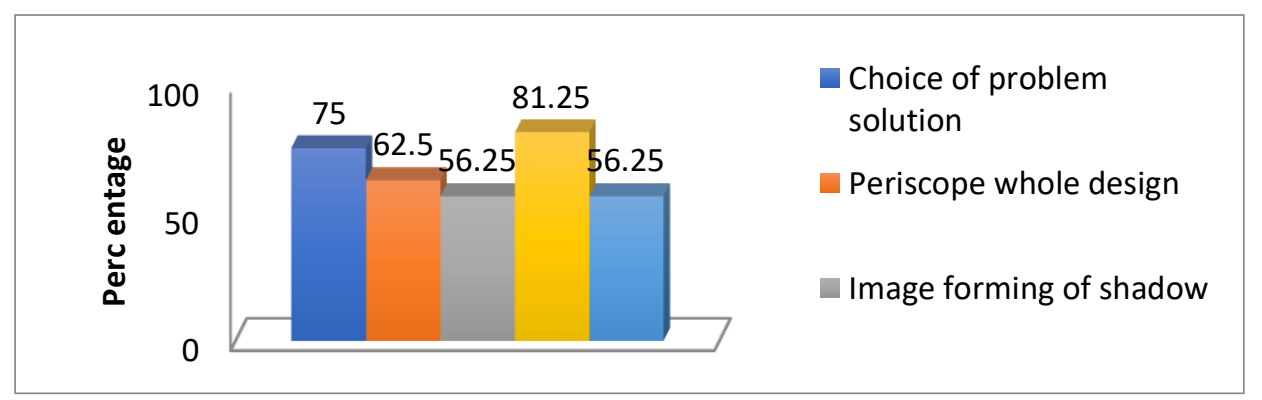

Fig. 1. Percentage of students in each aspect of the design process assessment.

Research data in picture 1 showed that in assessment aspect of material selection, all students have a percentage in the great category. This is shown by students' scores that reach $81.25 \%$. This result showed that students are great in the planning of material selection that exceeds the standard to design the prototype of simple periscope. Good material selection is considered from the endurance side, economic in material, and match with standard and problem background. This result also related to the students' skill in creative thinking that showed by the way of wide thinking and fluently in choosing good material regarding assessment standards.

For selecting problem solutions and periscope intact design, students showed a good score. This case is showed by the diagram pictured above with the percentage score continuously reach $75 \%$ and $62.5 \%$. The selection problem solution is based on the exact solution for solving the problem. It is related to the students' creative thinking in widely thinking and fluently thinking. In intact design score of periscope that suitable for to process of an assessment design standard. The result also showed students' creative thinking skills in a thinking manner of originality. Although in the good percentage, however, this score feels like they have the lowest score and almost reach enough number. It showed that students are not capable enough $\mathrm{n}$ designing intact periscope with assessment standard. Most of them also have a design that almost identical to other groups. 
Aspect 4th and 5th are the lowest aspects have a similar percentage that is $56.25 \%$ with enough interpretation. This is shown that assessment aspects of creating shadow pictures and design scale part is good enough conducted by students. As is the criteria of designing assessment process, in the process students have weaknesses in drawing shadow creation and designing periscope part. Most of the students are not creating scale and shadow lines that appropriate with assessment standard.

\section{Conclusion}

According to the discussion above, it can conclude that students' creative thinking skill in the design process with STEM approach has a good score. It is showed by Figure 1, which one aspect of material selection has a very good score. While for the aspect of drawing shadow creation and part design scale have enough score. The major percentage is influenced by students' creative thinking skills.

Acknowledgments. The author would like to thank Mrs. Irma Rahma Suwarma, M.Pd.,Ph.D. Dr. Lilik Hasanah, S.Si., M.Si. as the mentors of journal article writing who have helped in the preparation of research instruments and also have given enthusiasm and motivation to the author in completing this article. The author also expressed his gratitude to the head of Senior High School Ferdy Ferry Putra Jambi who gave the author permission to conduct research at the school.

\section{References}

[1] Florida R., Mellander C. and King Karen.: The Global Creativity Index (2015)

[2] Kemendikbud.: Pedoman implementasi kurikulum abad ke-21 untuk tahun 2013 di sekolah menengah (2017)

[3] Treffinger, D.J., Young, G.C., Selby, E.C. Shepardspon, C.: Assesing Creativity: A Guide for Educators, The National Research Center On The Gifted And Talented. Florida (2002)

[4] Dugger E.W. and Fellow, S .: Evolution of STEM in the United States (2010)

[5] Torlakson, T.: Innovate: A Blueprint for Science, Technology, Engineering, and Mathematics in California Public Education. California: State Superintendent of Public Instruction (2014)

[6] Pfeiffer, H.D., Ignatov, D.I., and Poelmans, J.: Conceptual Structures for STEM Research and Education. Mumbai: 20 th International Conference on Conceptual Structures (2013)

[7] Suwarma, I.R.: Research on Theory and Practice STEM Education Implementation in Japan and Indonesia using Multiple Intelligences Approach (Dissertation). Graduate School of Science and Technology Educational Division, Department of Information Science and Technology, Shizuoka University, Shizuoka (2015)

[8] Szu-Chun, C.F. and Ritz J.M.: International views of STEM education Pupil's Attitudes toward technology conference proceedings, pp. 7-14. Orlando (2014)

[9] National Research Council, National Academy of Engineering and committee on technological Literacy.: Technically speaking: Why all Americans need to know more about technology. Washington, DC: National Academy Press. (2002)

[10] Tayal, S.P.: Engineering Design Process International Journal of Computer Science and Communication Engineering IJCSCE Special issue on "Recent Advances in Engineering \& Technology", pp. 1-5 (2013)

[11] Ernst, J. and Glenice, E.: Redesigned High Schools for Transformed STEM Learning: Performance Assesment Pilot Outcome Journal of STEM Education, pp.27-35 (2015) 